\title{
VOTING WEIGHTS AND FORMATEUR ADVANTAGES IN THE FORMATION OF COALITION GOVERNMENTS ${ }^{1}$
}

\author{
Stephen Ansolabehere \\ Department of Political Science \\ Massachusetts Institute of Technology \\ James M. Snyder, Jr. \\ Department of Political Science and Department of Economics \\ Massachusetts Institute of Technology \\ Aaron B. Strauss \\ Department of Political Science \\ Massachusetts Institute of Technology \\ Michael M. Ting \\ Department of Political Science and SIPA \\ Columbia University
}

July, 2003

\footnotetext{
${ }^{1}$ James Snyder and Michael Ting gratefully acknowledge the financial support of National Science Foundation Grant SES-0079035. Michael Ting also acknowledges the financial and intellectual support of the Center for Basic Research in the Social Sciences at Harvard University. Stephen Ansolabehere gratefully acknowledges the support of the Carnegie Corporation under the Carnegie Scholars program.
} 


\begin{abstract}
We examine the relationship between parliamentary seats and cabinet posts in European governments between 1946 and 2001. Our specification improves on past studies in two respects. First, it derives and uses the voting weights of the underlying coalition formation games. This reduces the measurement error introduced when seat shares are used to proxy for voting weights. Second, the statistical model allows us to nest the predictions of different formal theories of the distribution of posts. We find that for non-formateur parties in the government, there is a linear relationship between their share of the voting weight in parliament and their share of cabinet posts. Additionally, the formateur party receives a substantial "bonus" relative to its voting weight. The latter finding is more consistent with proposal-based bargaining models of coalition formation, and less so with demand-bargaining models.
\end{abstract}




\section{Introduction}

In modern democracies, the legislature collectively decides how to divide public funds and positions of political power. Legislative representation, it is hoped, will lead to fair distribution of government resources to all interests in society. But, majority rule, it is feared, may lead to the dominance of the large parties or groups over the small and to the abandonment of societies' norms of equity (e.g., Dahl, 1956).

Political scientists have studied the division of government resources and positions in a wide range of settings to measure the political power of competing parties and interests and to test and refine theories of coalition formation. Examples of empirical research on power include the geographic distribution of public expenditures, the allocation of patronage positions in cities, the assignment of committee positions in Congress, and the allocation of cabinet posts in parliamentary coalition governments. ${ }^{1}$ Guiding this research are analytical models, some formalized and others not, where many players or parties bargain over the division of government positions or resources.

In this paper, we study one of these important situations: the allocation of cabinet ministries in coalition governments. We focus on two empirical questions about the formation of coalition governments that have immediate positive and normative implications: How are cabinet posts divided among the parties in the governing coalition? Who is chosen to form government, and does the choice matter?

A central theoretical conjecture holds that if a party is included in the government, then

1 The literature on this first topic is vast - see, e.g., Browning (1973), Wright (1974), Ritt (1976), Owens and Wade (1984), Wallis (1987, 1996), Atlas et al. (1995), Levitt and Snyder (1995), Lee and Oppenheimer (1999), Gibson, Calvo, and Falleti (1999), Horiuchi and Saito (2001), Stromberg (2001), Ansolabehere, Gerber and Snyder (2002), and Rodden (2002). On the second topic, see Holden (1973), Rakove (1975), Erie (1978), and Johnston (1979); on the third topic see, e.g., Shepsle (1978); and on the last topic see Browne and Franklin (1973), Schofield (1976), Browne and Frendreis (1980), Schofield and Laver (1985), Carmignani (2001), and Warwick and Druckman (2001). 
its payoff will be proportionate to its relative voting strength in the governing coalition. This idea was developed by Gamson (1961), and was formalized in as "demand-based" bargaining (e.g., Bennett and Van Damme, 1991; Selten, 1992; Morelli, 1999). It is also a prediction of various cooperative solution concepts, including bargaining aspirations (e.g., Bennett, 1983a, 1983b).

Another important class of models predicts that the way the governing coalition is formed will affect the division of the spoils. In particular, the party that proposes a government, the formateur, receives a share of the government positions disproportionate to its share of votes in the legislature. The other parties in the government, the coalition partners, receive payoffs that are proportionate to their voting strength. These "proposal-based" models were developed by Baron and Ferejohn (1989), Harrington (1990a), and others, following on the pioneering work of Selten (1981) and Rubinstein (1982).

A number of empirical papers have tested these ideas using data on coalition governments in western democracies. Browne and Franklin (1973), Browne and Frendreis (1980), Schofield and Laver (1985), Warwick and Druckman (2001), and others examine the relationship between parties' shares of parliamentary seats and their shares of cabinet positions. Specifically, these analyses find that a party's share of cabinet posts is linearly related to its share of legislative seats in the governing coalition. The relationship is so strong and robust that some researchers call it "Gamson's Law." In addition, these analyses find that there is little or no advantage to being formateur. The estimate coefficient on variables identifying the formateurs are typically small and statistically insignificant. ${ }^{2}$ These estimates are of critical importance for the development of analytical theories, as they contradict a basic proposition of proposal-based bargaining models, which have proliferated in recent years, and suggest an alternative approach to coalition theory, such as the demand-based bargaining.

There is, however, a critical weakness with these empirical studies. In all bargaining

\footnotetext{
${ }^{2}$ One exception is Warwick and Druckman (2001), who find a noticeable formateur effect after weighting cabinet posts according to their "importance".
} 
models, the theoretically relevant measure of a party's bargaining potential or strength is its share of the voting weight in parliament, not its share of the seats. ${ }^{3}$ However, all previous statistical analyses relate parties' seat shares to their shares of cabinet posts. Seat shares do not generally equal voting-weight shares, and the approximation can be quite poor. As a result, the regression analyses using seat shares in lieu of voting weight shares will produced biased estimates of both the formateur effect and the voting weight. ${ }^{4}$

This paper makes three specific contributions. First, we examine the relationship between seat-shares and voting weights. One reason past studies have used seat shares rather than voting weights is that it is difficult to calculate these weights. We have developed an algorithm to calculate the minimum integer weights for a wide class of games (see Strauss, 2003).

Second, we develop a simple statistical model that allows us to nest a variety of formal bargaining models, including the most prominent proposal-based and demand-based bargaining models. This allows us to provide a relatively precise interpretation of the estimated coefficients, and to conduct strong statistical tests of the predictions of specific theoretical models.

Finally, we analyze the relationship between parties' shares of voting weights and their shares of cabinet posts, using an augmented version of the data set developed by Warwick and Druckman (2001). We estimate the effect of being formateur, and how voting weights translate into shares of cabinet posts in parliaments.

We find that formateurs do enjoy sizable advantages. Also, after controlling for the formateur "bonus", there is a linear relationship between a party's share of the voting weight

\footnotetext{
${ }^{3}$ More precisely, the measure of a party's bargaining strength is the party's voting weight in a minimum integer representation of the underlying weighted voting game, or of some closely related game. See, e.g., Theorem 3 in Bennett and Van Damme (1991), Propositions 2 and 3 in Morelli (1999), and Propositions 1 and 2 in Snyder, Ting and Ansolabehere (2002).

${ }^{4}$ For the formateur effect to be biased it must also be the case that voting weights are correlated with formateurs. This is in fact the case, as shown in section 5 .
} 
share in parliament and the share of cabinet posts it receives if it is part of the governing coalition. This suggests a more subtle interpretation to the importance of a party's numerical strength and its power within the legislature. The large do not clearly dominate, but they may gain advantages from forming governments. These results also indicate that the proposal-based bargaining models, such as that of Baron and Ferejohn, capture an essential feature of distributive politics - the advantage to being proposer.

\section{Theory and Specification}

In this section we derive a simple statistical model that captures the predictions of a variety of different cooperative and non-cooperative bargaining models of coalition formation. We focus on bargaining models that make explicit predictions about the ex post distribution of payoffs - the actual division of government posts given that a particular coalition has formed. Many cooperative game theory solutions commonly used to study power, such as the Shapley-Shubik and Banzhaf indices, only characterize the ex ante distribution of expected payoffs (Shapley and Shubik, 1954; Banzhaf, 1965).

The distinction between ex ante and ex post payoffs is important for empirical research, since some subjects and data concern the ex post division and some may be better understood as ex ante. Data on the distribution of public expenditures, in which a large number of separate budgetary and appropriations decisions are pooled and averaged, are perhaps best compared to the ex ante predictions of non-cooperative models, or to power indices. Data on coalition governments apply directly to the ex post predictions of non-cooperative models because the data available concern specific coalitions that have formed in particular ways (e.g., in each case observed, a specific party was recognized as formateur and succeeded in forming a government).

The equilibria of non-cooperative bargaining models in which decisions are made by majority rule - or any quota rule short of unanimity in which there are no veto players typically feature a "competitive-pricing" condition. This states that the "price" required to secure a player's vote must be proportional to the player's voting weight. Some cooperative 
solution concepts, such as bargaining aspirations, share this feature (see, e.g., Bennett, 1983a, 1983b). The logic is straightforward. Consider two players ( $A$ and $B$ ) each with 1 vote, and one player $(C)$ with 2 votes. Player $C$ is a perfect substitute for the pair $\{A, B\}$ in terms of forming winning coalitions - each brings 2 votes to a coalition. Competition will then drive the price of $A$ 's to vote be the same as the price of $B$ 's vote, and it will also drive the price of player $C$ 'two votes to be exactly twice that of $A$ 's (or $B$ 's) vote. That is, if $A$ 's vote costs $c$ cents, then $B$ 's vote will also cost $c$ cents and $C$ 's votes will cost $2 c$ cents.

Consider a weighted voting game in which $n \geq 3$ players bargain over the division of one "dollar." Let each player $i$ 's individual voting weight be $w_{i}$, and let the total voting weight in the game be $W=\sum_{i}^{n} w_{i}$. To keep things simple, we restrict attention to homogeneous games, which share the feature that all minimal winning coalitions have the same weight. Homogeneous games have a unique minimal integer representation (see Isbell, 1956); assume that the $w_{i}$ 's are these minimal integer weights. Then the total voting weight of each minimum winning coalition is $(W+1) / 2$ for $W$ odd and $W / 2+1$ for $W$ even. We focus on the case of odd $W$ and note that the following derivation is virtually identical for even $W{ }^{5}$

Suppose player $j$ is the formateur. Then $j$ will construct a minimal winning coalition and pay each member $c$, and will pay zero to all the excluded players. Let $x_{i}$ denote the $e x$ post distribution of payoffs. Then for each $i \neq j$ :

$$
x_{i}= \begin{cases}c w_{i} / W & \text { if } i \text { in coalition } \\ 0 & \text { if } i \text { not in coalition, }\end{cases}
$$

where $c$ is the price per unit of voting weight that must be paid to coalition partners. The total amount paid by the formateur is therefore $c \frac{W+1}{2 W}$, and the formateur's share of the dollar is:

$$
x_{j}=1-c \frac{W+1}{2 W}+c \frac{w_{j}}{W} .
$$

This is the dollar minus the amount paid to all coalition partners plus the amount that the formateur did not have to pay to itself because of her own votes.

\footnotetext{
${ }^{5}$ For some non-homogeneous games, the formulation below will only approximate the true relationship.
} 
The competitive-pricing condition leads immediately to a statistical specification. Let the dependent variable, $Y_{i}$, be the share of cabinet posts distributed to each party in a coalition. Let $F_{i}$ be an indicator of whether party $i$ is formateur of a government. Then,

$$
\begin{aligned}
Y_{i} & =F_{i}\left[1-c \frac{W+1}{2 W}+c \frac{w_{i}}{W}\right]+\left(1-F_{i}\right)\left[c \frac{w_{i}}{W}\right] \\
& =\left[1-c \frac{W+1}{2 W}\right] F_{i}+c \frac{w_{i}}{W} .
\end{aligned}
$$

Hence, a reasonable statistical specification is to regress parties' shares of posts on their shares of voting weights in the legislature, an indicator variable for formateur, and a constant:

$$
Y_{i}=\beta_{0}+\beta_{1} F_{i}+\beta_{2} \frac{w_{i}}{W}+\epsilon_{i}
$$

If the theoretical model is exact, then the intercept, $\beta_{0}$, should equal zero. The coefficient $\beta_{2}$ provides an estimate of the price per unit of voting weight, $c$. The coefficient $\beta_{1}$ provides an estimate of $\left[1-c \frac{W+1}{2 W}\right]$. Note that $\beta_{1}$ also depends on $c$, as well as the total voting weight of the legislature, $W$. The ratio $(W+1) / 2 W$ is close to $1 / 2$, except for legislatures where the total voting weight is small. Thus, another specification check is whether the estimates of $\beta_{1}$ and $\beta_{2}$ imply the same value of $c$. Using the approximation $(W+1) / 2 W \approx 1 / 2$, this means $\beta_{1} \approx 1-\beta_{2} / 2 .{ }^{6}$ Further violations of the specification are non-linearities, either in the form of polynomials or interactions, which we examine as well.

Different models yield different values of $c$. Gamson's Law, which Morelli (1999) derives from a demand bargaining model, predicts that $x_{i}=w_{i} / W$ for all players in the governing coalition, including the formateur. ${ }^{7}$ Thus, if Gamson's Law holds then $c=\frac{2 W}{W+1} \approx 2$. The weighted-voting version of the Baron-Ferejohn legislative bargaining model with a closed

${ }^{6} \mathrm{~A}$ more complete specification, which incorporates the fact that $\frac{W+1}{2 W}$ is not a constant but depends on $W$, is: $Y_{i}=\beta_{0}+\beta_{1} F_{i}+\beta_{4} \frac{w_{i}}{W_{k}}+\beta_{3} \frac{W_{k}+1}{2 W_{k}}+\beta_{2} F_{i} \frac{W_{k+1}}{2 W_{k}}+\epsilon_{i}$, where $W_{k}$ is the size of the $k$ th legislature. We are unable to estimate this model, however, because of problems of severe multicollinearity.

${ }^{7}$ See also Bennett and Van Damme (1991), who derive this from a different demand bargaining model for a special class of weighted voting games (apex games). 
rule and no discounting predicts that $c=1$. That is, coalition partners are paid exactly their share of the total weight in the legislature, and the formateur receives a large surplus (see Snyder, Ting, and Ansolabehere, 2002). ${ }^{8}$

Variants on these models can produce other values of $c$. It is implausible that $c>2$, because then there would be no incentive for any formateur to build a coalition. Political parties would prefer to be coalition partners instead. Risk aversion and discounting will tend to produce $c<1$. These features increase the incentive of coalition partners to accept a proposal, thus lowering their price and strengthening the formateur's advantage. Bargaining under an open rule will tends to produce $c>1$. Supermajority rules that raise the number of votes required to form a government, will tend to reduce the formateur's surplus, and may also increase $c$. Requiring the governing coalition to obtain bicameral support will have similar effects. ${ }^{9}$

Two features of the bargaining models, then, are relevant for statistical estimation. First, a linear regression relating shares of posts to shares of voting weights can be used to measure the "price" of coalition partners and the formateur effect and, thus, to test the key conjectures of the bargaining models. Second, the theoretically appropriate independent variable that measures a party's bargaining strength is that party's share of the voting weights in the legislature.

\section{Seats and Weights}

All formal bargaining model results are expressed in terms of voting weights, not seat

${ }^{8}$ Again, there is the caveat that non-homogeneous games will deviate slightly from these predictions. For homogeneous games, the results are exact.

${ }^{9}$ Baron and Ferejohn (1989), Harrington (1990a), and others prove many of these results for the case of unweighted majority games. The extension to weighted voting games appears to be straightforward. Diermeier, Eraslan, and Merlo (2002) analyze a proposal-based game with bicameral governments. They note that Italy, Belgium (until 1995), and Sweden (until 1970) are the only European parliaments that require bicameral support of the government. 
shares. Voting weights offer a more direct measure of a party's bargaining potential. They can be derived from seat shares, but the relationship is not an immediate one.

An example illuminates the calculation of voting weights. Consider a legislature with four parties. Party A has 6 seats, parties B and C have 5 seats, and party $\mathrm{D}$ has 1 seat. The minimal winning coalitions are $\{\mathrm{A}, \mathrm{B}\},\{\mathrm{A}, \mathrm{C}\}$, and $\{\mathrm{B}, \mathrm{C}\}$. Party $\mathrm{D}$ is always a surplus member in any winning coalition, and is therefore never a member of a minimum winning coalition. Parties A, B, and $\mathrm{C}$ all have the same voting weight, even though they have different numbers of seats. The minimal integer voting weights for this game, then, are $(1,1,1,0)$.

The mathematical convenience of minimum integer voting weights, however, masks an important complication in linking theory to data. Seat shares, which researchers observe, do not map readily into voting weights, which theorists analyze.

The error in the approximation is three-fold. First, many different divisions of the seats can correspond to a single minimum integer weight representation. This is most apparent for three party games (in which no party has an outright majority), where all coalition games have the minimum integer representation of $(1,1,1)$. Second, the relationship between the share of minimum integer weights and the average share of seats is not linear. According to Penrose's (1946) approximation, it is approximately logarithmic. Third, looking across games, as is done in regression analyses, a party's share of the seats may correspond to many different shares of minimum integer weights. Consider, for example, the following two situations. In case (i) the distribution of seats is $(4,3,1,1)$, and in case (ii) the distribution is $(4,2,2,1)$. In case $(i)$ the minimum integer weights are $(3,2,1,1)$, so the first party's $4 / 9$ share of the seats corresponds to a $3 / 7$ share of the voting weight, and the fourth party's $1 / 9$ shares of the seats corresponds to a $1 / 7$ share of voting weight. In case (ii), the distribution of seats is equal to the minimal integer weights. The first party's $4 / 9$ share of the seats then corresponds to a $4 / 9$ share of the voting weight, and the fourth party's $1 / 9$ shares of the seats corresponds to a $1 / 9$ share of voting weight.

Empirical studies of coalition formation that use shares of seats to measure bargaining 
strength suffer from measurement error. The measurement error will be both random and systematic, as the correspondence between seats and weights is not one-to-one and not linear. Standard regression analyses will therefore produce biased estimates of the bargaining advantage that parties gain solely from their "votes". Of particular concern, Browne and Franklin (1973), Browne and Frendreis (1980), Warwick and Druckman (2001), and others use seat shares as a proxy for shares of voting weights to predict the division of cabinet posts. The coefficient on seat shares will tend to be biased toward zero as a result of measurement error. Warwick and Druckman (2001) also include a dummy variable for the party chosen to serve as formateur. They find that the formateur effect is small and not different from zero, but note that measurement error in the voting weights might bias the estimated formateur effect. ${ }^{10}$

To gauge the possible extent of biases due to measurement error, we will first investigate how badly seat shares approximate voting weights.

One reason researchers use seat shares instead of shares of voting weights is practical voting weights are difficult to calculate. One must first enumerate all possible coalitions and then search the space of all possible coalitions for sets of identical coalitions with smaller integer voting weights. We calculate the minimum integer voting weights for all parliaments using an algorithm developed by Strauss (2003). ${ }^{11}$

Figure 1 shows the empirical relationship between parties' Shares of Seats and their Shares of Voting Weights in parliamentary governments from 1946 to 2001. It covers all parliaments in 14 countries - Australia, Austria, Belgium, Denmark, Finland, Germany, Iceland, Ireland, Italy, Luxembourg, the Netherlands, Norway, Portugal, and Sweden - in which no single party had an outright majority. This is approximately the same set of countries and parliaments used in previous analyses. ${ }^{12}$

\footnotetext{
${ }^{10}$ Random measurement error alone is sufficient to create these biases.

${ }^{11}$ This algorithm can be accessed at http://www.zzz. The Paradise lab at Caltech has developed alter native algorithms; see http://www.paradise.caltech.edu for details.

${ }^{12}$ For example, Warwick and Druckman (2001) study all of these countries except Australia and Portugal,
} 
[Figure 1 here]

Several highly non-linear features of the data stand out in Figure 1. First, there is a cluster of dummy players at the bottom left, some having as much as 10\% of the legislative seats, but no voting weight. Second, there are a large number of parliaments with three and four parties. The voting weights for all three player games are $(1,1,1)$ and the weights for four player games are $(2,1,1,1)$. These ratios appear in the graphs as horizontal clusters of cases voting weight equal $1 / 3$ in the first case and $2 / 5$ and $1 / 5$ in the second case.

The linear regression relating Shares of Seats to Shares of Voting Weights gives a firstorder approximation to the measurement error. The intercept and slope are indicative of systematic measurement error. The estimated slope equals $1.02(\mathrm{se}=.016)$ and the intercept is $-.01(\mathrm{se}=.002)$. In other words, seat shares tend to overstate the voting weights of larger parties and understate the voting weights of very small parties. In addition, the systematic component of the measurement error is not linear. We added squared and cubic terms to the regression, and excluded dummy players and parliaments with fewer than 5 parties. The coefficients on Voting Weight Shares, Voting Weight Shares Squared0 and Voting Weight Shares Cubed are .73, 1.46, and -1.87, respectively. All have absolute t-values larger than 3.

There is also noticeable random measurement error. The linear regression of seat shares on voting weight shares has an $R^{2}$ of .78, high but not close to 1 . The mean squared error, an estimate of the standard error of the measurement error, is .077. This is more than one-half of the standard deviation of voting weight shares $($ s.d. $=.114)$, which implies a relatively large amount of measurement error. ${ }^{13}$ This amount of measurement error can affect both the estimated effect of voting weights on shares of positions of power, and the estimated formateur effect. Whether it actually does is an empirical matter, to which we now turn.

\section{Coalitions and Cabinet Allocations}

over the period 1946-1989. See section 4 below for details on data sources.

${ }^{13}$ These results are for the subset of parties in coalition governments. The results are similar for the entire sample. 
The distribution of cabinet portfolios in parliamentary coalition governments provides an excellent field in which to test the ex post predictions of bargaining models. Researchers can readily observe voting weights of parties, who forms coalitions and the allocation of cabinet ministries.

We study coalition governments from 1946 to 2001 in Australia, Austria, Belgium, Denmark, Finland, Germany, Iceland, Ireland, Italy, Luxembourg, the Netherlands, Norway, Portugal, and Sweden. Data on parties' seat shares, government cabinet post allocations, and formateurs are from the following sources: data generously supplied by Paul Warwick, used in Warwick (1994); Brown and Dreijmanis (1982); Mueller and Strom (2000); and the European Journal of Political Research "Political Data Yearbook" special issues, 1992-2001. ${ }^{14}$ As in all previous work on government formation, we assume that each party's members vote as a bloc, and therefore each parliament may be viewed as a weighted voting game.

One difficulty with the parliamentary data is that the value of the different cabinet ministries is unknown. Almost all prior research has treated all posts as equally valuable. Because the aim of this research is to show the value of the statistical model derived above and the importance of using weights instead of seats, we start with this measurement convention as well. Laver and Hunt (1992) and Warwick and Druckman (2001) offer thorough discussions of the values of different ministries. Laver and Hunt survey party leaders and find that Prime Minister is by far the most valuable post, usually followed by Finance and Foreign Affairs. It is difficult, however, to measure the relative valuation of the ministries beyond the obvious difference between Prime Minister and all others. Following Warwick and Druckman

\footnotetext{
${ }^{14}$ Following previous researchers, we include all governments, including minority governments and nonminimal-winning governments, except a few cases where one party had an outright majority but still formed a coalition government. These cases were in the period immediately following WWII in the former axis powers, Austria, Italy, West Germany, plus a few in Australia. France is not included in the sample because of the fluid nature of the parties. We have yet to find a consistent data set on the votes, seats and cabinet portfolios of French parties.
} 
(2001), we also analyze the data under the assumption that the post of prime minister is more valuable than other ministries. ${ }^{15}$ Specifically, we assign a relative value of 3 for prime minister and a value of 1 for all other posts. This is surely a poor approximation, and truer measures the of value of posts would improve the estimates further.

We estimate the specification developed above using both the simple and weighted shares of cabinet ministries as the dependent variable.

\subsection{Statistical Analysis}

Consider three party legislatures - those with weights $(1,1,1)$. This is the most common alignment of party voting weights, covering 36 of the 240 parliaments in the data. Three party legislatures do not fit Gamson's Law, but they do fit the simple, closed-rule, BaronFerejohn model of proposal-based bargaining rather well. Any two parties form a minimum winning coalition, and each party's share of the voting weights within the government is $1 / 2$. Gamson's Law predicts that the parties will split the posts 50-50. The Baron-Ferejohn game predicts that the formateur should receive $66.7 \%$ of the posts in these games, and the partner $33.3 \%$. In fact, on average the party that proposes the coalition government receives $63 \%$ of the government posts (without giving additional value to the prime minister). This is slightly less than predicted by the Baron-Ferejohn model. The standard deviation of the division of posts is .11. The $t$-statistic for the hypothesis that the formateur's expected share is .5 is 7.06, so one would reject Gamson's Law in these cases. Giving added value to the prime minister's post increases the formateur's share of government posts to $68 \%$, with a standard deviation of .09. The $t$-statistic is now 11.83, and one can again reject the hypothesis that government posts are divided in proportion to parties' relative voting weights. By contrast, one cannot reject the hypothesis that the formateur receives $66.7 \%$ of the posts, as predicted by the Baron-Ferejohn model.

The multivariate regression model developed above provides a more general framework

\footnotetext{
${ }^{15}$ Warwick and Druckman (2001) use the ministerial rankings in Laver and Hunt to estimate values for all ministries. We do not at tempt that here.
} 
within which to test the overall appropriateness of the bargaining models. It also allows us to estimate of the price of coalition members' votes, $c$.

Table 1 presents two regressions. In column (1) the dependent variable is the Share of Posts that a party received. In column (2) the dependent variable is the Weighted Share of Posts, where the post of Prime Minister has a weight of 3. We regress parties' shares of cabinet posts on their Shares of Voting Weights and on an indicator for the Formateur.

[Table 1]

The regression analyses show a significant formateur advantage. In column (1), the coefficient on the indicator of Formateur is .15, with a standard error of .015. The immediate interpretation of this coefficient is that a party receives $13 \%$ more of the ministries when it forms the government than when it does not, holding constant that party's share of the overall voting weight. The average government has 15 posts, so the estimated formateur effect translates into approximately 2 additional ministries. In column (3), the estimated formateur effect is .25, which translates into approximately 4 additional (weighted) posts.

The large and statistically significant coefficient on Formateur is evidence against Gamson's Law and the demand-bargaining approach. However, the data also reject the simple, closed-rule version Baron-Ferejohn model. The average value of $(W+1) / 2 W$ in the data is .55 , so the Baron-Ferejohn model predicts that the formateur effect should be approximately .45. The estimated formateur effect in column (1) is just one-third of the predicted value, and the estimate in column (3) is one-half of the predicted value.

The coefficient on voting weight shares, $\beta_{1}$, is close to 1 . In the first panel, the regression coefficient is significantly larger than one, but the difference in the second panel, when Prime Minister is given added value, is not statistically different from 1 . Thus, the estimated price of votes is about 1 or slightly higher. In both cases the data overwhelmingly reject the hypothesis that $\beta_{1}=2$.

Overall, the coalition government data are more consistent with the proposal-based bargaining approach than the demand-based approach. The three-party parliaments adhere quite closely to the predictions of the simple Baron-Ferejohn model. Looking across all par- 
liaments, the regressions produce an implied price of approximately $c=1$ or slightly higher, and a substantial formateur advantage.

The data also show the effects of measurement error and of the specification. Past research differs from the regressions in Table 1 in two ways. First, past research uses seat shares instead of voting weights. Second, past research specifies the variables to be conditional on being in the government. Specifically, in Browne and Franklin (1973) and subsequent papers, seat shares are calculated as a fraction of the total seats of parties in the government, rather than as a fraction of all seats in the legislature. The theoretically appropriate specification uses voting weights as a fraction of all legislative voting weight. Past research, then, uses the wrong measure of bargaining strength (i.e., seat shares instead of minimum integer voting weights) and calculates this against the wrong baseline (i.e., only those in the government instead of all of the legislature).

Table 2 shows the consequences of these two specification errors. In all four specifications seat shares are used in stead of voting weights. The first two regressions in the paper replicate specifications used in the prior research. ${ }^{16}$ In Columns (1) and (2), the independent variable is a party's share of the seats among all parties that are in the government, called Share of Seats In Government. The second two regressions isolate the effects of measurement error alone. Columns (3) and (4) parallel the specifications in Table 1. The independent variable is a parties share of all seats in the legislature, called Share of All Seats. Minimum integer voting weight as a fraction of all parties' voting weight is the baseline predicted by the theor etical analyses.

[Table 2]

The specification reported in Column (1) replicates past findings about formateurs. The estimated coefficient on Formateur is tiny and statistically indistinguishable from 0. Giving the Prime Ministerial post a weight of 3 yields a larger and statistically significant formateur effect of $.13 .{ }^{17}$ However, it is difficult to interpret this number since it is not tied clearly to

\footnotetext{
${ }^{16}$ See, e.g., Equation 1 of Browne and Franklin (1973) or Table 2 of Warwick and Druckman (2001).

${ }^{17}$ This is similar to results in Warwick and Druckman (2001).
} 
any analytical model.

Comparing columns (3) and (4) in Table 2 with columns (1) and (3) in Table 1 reveals the consequences of measurement error introduced by seat shares. The coefficients on Share of Seats are about one standard error lower than the coefficients on Share of Voting Weight. More noticeably, the coefficients on Formateur are substantially lower when seat shares are used instead of voting weights. Comparing column (3) of Table 2 with column (1) of Table 1 , when seat shares are used the estimated formateur effect is .07 , less than half as large as the estimated effect using voting weights.

Finally, we should note that the estimated formateur effects in Table 1 are not simply capturing the numerical advantage of the largest party, which is often the formateur. We conducted analyses parallel to those in Table 1 but omitting all coalitions in which the largest party was the formateur. The results are very similar. Specification (1) produces a formateur effect of $.14(\mathrm{se}=.02)$ and a slope on voting weights of 1.23 ( $\mathrm{se}=.09)$. Specification $(2)$ produces a formateur effect of $.23(\mathrm{se}=.02)$ and a slope on voting weights of $1.09(\mathrm{se}=.08)$. The sample size is smaller $(\mathrm{n}=254)$, and the $R^{2}$ is somewhat smaller but still respectable (.63 and .74 in specifications (1) and (3), respectively).

\subsection{Specification Checks}

While the data support important intuitions captured by non-cooperative bargaining models, especially the Baron-Ferejohn model, the empirical analysis does not provide a perfect fit.

Three important specification checks are contained in the regression model. First, we tested for the linearity of the relationship between weight shares and post shares. One approach is to use a polynomial specification of voting weight shares. Including weight share, weight share squared, and weight share cubed did not affect the estimated formateur effects. The formateur effect is .15 with a standard error of .02 using unweighted data and .25 with $\mathrm{SE}=.02$ using weighted data. The coefficient on weight share went up somewhat in both specifications. Neither weight share squared nor weight share cubed had statistically 
significant effects on their own, though an $F$-test shows that one cannot reject their joint significance. The problem is that weight share squared and cubed are correlated .98 and are highly collinear with weight share.

A related non-linear specification looks for interactions among the independent variables. We also estimated interactive terms, Formateur $\times$ Share of Weight, for each of the specifications. The interaction effect picks up some of the formateur effect in the regression. But, again, there is a high degree of collinearity. Formateur and Formateur $\times$ Share of Weight are correlated .93. In sum, it is difficult to justify and estimate a non-linear specification with the parliamentary data because Share of Voting Weight is highly correlated with polynomials of that variable and interactions with the Formateur indicator.

Two additional checks apply to the overall competitive-pricing bargaining framework. One implication of the competitive pricing condition is that the constant term in the regression ought to equal zero. The constant is .07 in column (1) of Table 1, and .06 in column (2). This translates into about 1 cabinet post in the average coalition government. The estimates are statistically different from 0 , violating both the proposal-based and demand-based bargaining models.

A second test derives from the analytical model presented in section 4.1. The prices implied by the formateur effect should be consistent with those contained in the slope parameter. Looking at specification (1), the value of $c$ estimated directly from the coefficient on Share of Voting Weight in the legislature is 1.12. The implied value of $c$ from the coefficient on Formateur is approximately 1.55. ${ }^{18}$ The $F$-statistic for testing the hypothesis that the estimated values of $c$ are equal is 18.0 , with a p-value less than .01. In specification (3) the implied estimates of $c$ are .98 and 1.36, respectively, the $F$-statistic for the hypothesis that they are equal is is 8.2, and the p-value again less than .01. Both models therefore fail this test.

\footnotetext{
${ }^{18}$ The coefficient on Formateur is .15 , and the average value of $(W+1) / 2 W$ is .55 , so the implied value of $c$ solves $.15=1-.55 c$.
} 
One possible explanation for the non-zero intercept and the difference in the implied prices is that ministries are "lumpy" goods. It may be impossible to divide a single post. As a result, the formateur may have to give away too much. Relatedly, theoretical models apply to homogeneous games, and about half of the coalition governments are non-homogeneous, which raises problems of rounding and cornering in calculating predicted divisions of ministries. A second possibility is that there may indeed be a particular fairness norm at work. If there is a minimum equity rule, then every party in a coalition gets one post; the remaining posts may be settled by non-cooperative bargaining. The exact explanation for the non-zero intercept deserves further attention.

The intercept might also arise because the theoretical models of bargaining do not predict an exact relationship between shares of posts and voting weights for all games. Specifically, when there is an even number of votes or when the game is non-homogeneous, small parties are, on average, predicted to receive slightly more than their share of voting weights. We conducted an analysis paralleling that in Table 1 but using the exact predicted payoffs of the simple, closed-rule Baron-Ferejohn model instead of Voting Weight Shares. The estimated value of the constant falls by half, but is still statistically distinguishable from 0 . The estimated formateur effect remains substantial, though below the predictions of the model, and the estimate of $\beta_{1}$ rises slightly. ${ }^{19}$

A final possible explanation concerns the measure of the value of the posts. We do not know the actual value that parties place on posts. This is a general problem in the study of coalition government on which there is recent progress. As noted above, Laver and Hunt (1992) find that there is considerable variation how parties rank different posts. Not knowing the exact values of different posts may bias our estimates. For example, we may overestimate the share of value gained by small parties if they tend to receive less valuable posts. Our crude attempt to correct for this problem by giving the Prime Minister a larger value is

\footnotetext{
${ }^{19}$ For the our sample of parliamentary governments, the regression of the simple Baron-Ferejohn payoffs on Voting Weight Shares has an intercept of .02, which is statistically different from 0, and a slope of .98.
} 
surely inadequate, and further research on the value of cabinet posts is needed.

\section{Formateurs}

The results above show that formateurs receive a disproportionate share of cabinet posts. One normative question motivating our research is the equity or fairness in the distribution of positions of power. To address this more fully we now turn to the question of who is formateur.

Diermeier and Merlo (1999) study formateur selection in parliaments of 12 countries. They examine the order in which parties are recognized to be formateur, and document that formateur selection is roughly proportionate to seat shares, with the additional caveat that the "incumbent" formateur is much more likely to be recognized first. As with other empirical studies, they control for seat shares, rather than voting weights.

Here, we examine which party succeeds in forming a government, rather than the order of recognition. If larger parties are disproportionately more likely to succeed, then they may gain undue bargaining advantages because they have more opportunities to make proposals.

The simplest case arises in parliaments where three parties have equal voting weights. A simple of notion of fairness holds that proposal probabilities reflect the number of voters represented by a party. There are 36 three-party coalition governments. On average the largest party has $44 \%$ of the seats; the second largest, $39 \%$; the third largest, $12 \%$; and the remaining seats are scattered across dummy parties. The largest party, with $44 \%$ of the seats, formed the government $72 \%$ of the time (i.e., 26 cases); the second largest formed the government $25 \%$ of the time; and the smallest parties formed the government only $3 \%$ of the time (1 case).

Table 3 presents a multivariate analysis of the likelihood that a party is formateur. The probability of being formateur is estimated as a function of a party's Share of Voting Weights, its Share of Seats, its rank (Largest Party and Second Largest Party), and an indicator of whether that party was formateur in the previous government (Incumbent Formateur). We use probit estimates with standard errors clustered for each coalition. We also modeled the 
data using conditional logits, which estimates a fixed effect for each coalition. The results were very similar.

[Table 3]

The probits suggest that larger parties have a disproportionately higher chance of being proposer than smaller parties. Columns (1) and (2) reveal that voting weight shares and seat shares separately predict who is formateur. Columns (3) and (4) reveals that party rank matters, perhaps even more than numerical strength. Including indicators of the largest and second largest parties, the coefficient on seat shares falls but remains statistically significant and the coefficient on voting weight shares is no longer significant on its own. The coefficients on largest party and second largest party reveal that controlling for the sizes of the party and their voting weight shares, the largest party is twice as likely as the second largest party to form a government. As with Diermeier and Merlo's findings, the party that formed the previous coalition government has a good chance to form the current government. This reflects, in part, the fact that many coalition governments reorganize between elections and the formateur selects a new set of partners.

We must treat these results with some cautrion, because there is a fair amount of collinearity among the independent variables. In particular, the coefficients on voting weight shares and seat shares may be poorly estimated in specifications (3) and (4). The auxiliary regression predicting voting weight shares with seat shares, party ranks, and formateur incumbency

has an $R^{2}$ of .91 . A joint $F$-test reveals that voting weights and seat shares are both highly significant $(\mathrm{p}<.0002)$.

Even still, the probit analysis and the analysis of the three party parliaments suggests that there is a large party bias in the ultimate selection of the formateur.

\section{Conclusions}

This paper improves on the growing research agenda on legislative bargaining in two important ways. First, we have introduced voting weights to the empirical study of parliamentary government formation. Prior research has used seat shares as a proxy for voting 
weight shares, owing to the difficulty in calculating voting weights. Second, we have developed a general statistical specification within which to nest two important bargaining models.

With these improvements we find a markedly different picture of the allocation of cabinet ministries than has been shown in prior studies. First, the allocation of cabinet posts is proportionate to voting weight shares. This finding is consistent with the general idea behind non-cooperative models of bargaining and coalition formation. These models begin with a conjecture that there is no opportunity for arbitrage. From that it follows that the price of coalition partners is proportionate to their voting weight: a party with voting weight 2 costs as much as two parties with weight 1 . The main empirical question is what is the price of a coalition partner.

Second, we document a substantial formateur advantage in coalition governments. This finding runs counter to Gamson's Law and demand-based bargaining models that justify it. This finding is consistent with proposal-based bargaining models as captured in Baron and Ferejohn (1989) and elsewhere. Also, the direct estimate of the price of a partner is approximately that predicted by the Baron-Ferejohn model.

Much of the current theorizing about legislative behavior and institutions employs proposalbased bargaining models. The literature is impressive, and includes at least twenty recent papers. ${ }^{20}$ Our results provide empirical support for this approach.

There are, however, two important violations of specific model examined that point to both the opportunity and need for further theoretical analyses.

That the Baron-Ferejohn model fails to provide an entirely consistent model of actual

\footnotetext{
${ }^{20}$ See Harrington (1989, 1990a, 1990b), Austen-Smith and Banks (1988), Baron (1991, 1996, 1998), McKelvey and Riezman (1992), Baron and Kalai (1993), Calvert and Dietz (1996), Winter (1996), Diermeier and Feddersen (1998), Banks and Duggan (2000), LeBlanc, Snyder and Tripathi (2000), McCarty (2000a, 2000b), Eraslan (2002), Jackson and Moselle (2002), Norman (2002), Snyder, Ting, and Ansolabehere (2002), and Ansolabehere, Snyder and Ting (2003).
} 
coalitions is perhaps not surprising. The model rests on some highly restrictive assumptions. For example, no amendments are allowed once a proposal is made. The open rule version of this game is analytically difficult to study, and the equilibria of general weighted voting games have yet to be characterized. A further assumption, which seems to be violated in the parliamentary data, is the random recognition rule in proportion to voting weights. Recognition depends on voting weights but also on seats - the largest party has the highest likelihood of forming a coalition - and, as Diermeier and Merlo (1999) find, on incumbency. In addition, the models studied here, and in much of the literature on distributive politics, do not capture the ideological component that runs through much politics. Even with these shortcomings, these simple models do surprisingly well at describing the distribution of cabinet portfolios.

Finally, we turn to two normative issues.

One important normative concern regards representation. The logic of non-cooperative bargaining models reveals an interesting point of potential disconnect between voters' preferences and the government. Votes won in elections translate into seats in parliament. But, seats do not necessarily map one-to-one into bargaining weight or voting weights within the legislature. The three party legislature where two parties have 100 seats and one party has 1 seat is a dramatic example of the problem. For simplicity, assume that there is proportional representation. The data at hand suggest that ex ante all three parties have equal bargaining power, or can expect (prior to the selection of a formateur) to receive the same share of parliamentary seats. But, the two larger parties represent 100 times as many voters. Because ministries make and implement public policies, the disconnect between public preferences and public policies is potentially quite large.

A second important concern with majority rule in parliaments is whether the large dominate the small. This concern dates back at least to Montesquieu and other 18th Century philosophers in their concern about the proper institutions for republican or democratic government. When there is a majority party, that party clearly dominates the legislature and controls the ministries. It is also sometimes argued that larger parties or interests tend to 
dominate in the formation of coalition governments (Banzhaf, 1965). This does not appear to be the case in most western parliaments. Aside from the formateur advantage, the allocation of ministries is proportionate to parties' voting weights.

The formateur advantage does suggest a route through which larger parties may dominate in legislative bargaining. The formateur advantage is substantial, and the largest party, more often than not, is the formateur. In part, this may be because recognition is proportionate to voting weights, as Diermeier and Merlo argue. We find that the largest party has an even higher likelihood of acting as formateur than predicted by the parties' shares of voting weights. It is through the power to propose, then, that larger parties apparently gain disproportionate political advantage.

An important theoretical question stemming from this inquiry, then, is why are larger parties more likely to form the government - a norm that tends to give larger parties disproportionate power. We suspect the answer lies with the broad question of accountability. It may be difficult for voters to hold a small party accountable for the successes or failures of the government. Thus, to maintain orderly elections in which voters can identify the main electoral choices and determine their consequences, it may be optimal to give larger parties the right to create coalition governments, but also to expose those parties to the risks associated with the failure of the coalition to govern. 


\section{REFERENCES}

Ansolabehere, Stephen, Alan Gerber and James M. Snyder, Jr. 2002. "Equal Votes, Equal Money: Court Ordered Redistricting and the Distribution of Public Expenditures in the American States." American Political Science Review, 96: 767-777.

Ansolabehere, Stephen, James M. Snyder, Jr., and Michael M. Ting. 2003. "Bargaining in Bicameral Legislatures: When and Why Does Malapportionment Matter?" American Political Science Review 97, forthcoming.

Atlas, Cary M., Thomas W. Gilligan, Robert J. Hendershott, and Mark A. Zupan. 1995. "Slicing the Federal Net Spending Pie: Who Wins, Who Loses, and Why." American Economic Review 85: 624-629.

Austen-Smith, David, and Jeffrey Banks. 1988. "Elections, Coalitions, and Legislative Outcomes" American Political Science Review 82: 405-422.

Banzhaf, John F., III. 1965. "Weighted Voting Doesn't Work: A Mathematical Analysis." Rutgers Law Review 19: 317-343.

Banks, Jeffrey S., and John Duggan. 2000. "A Bargaining Model of Collective Choice." American Political Science Review 94: 73-88.

Baron, David, and John Ferejohn. 1989. "Bargaining in Legislatures." American Political Science Review 83: 1181-1206.

Baron, David. 1991. "A Spatial Theory of Government Formation in Parliamentary System." American Political Science Review 85: 137-164.

Baron, David. 1996. "A Dynamic Theory of Collective Goods Programs." American Political Science Review 90: 316-330.

Baron, David. 1998. "Comparative Dynamics of Parliamentary Governments." American Political Science Review 92: 593-609. 
Baron, David, and Ehud Kalai. 1993. "The Simplest Equilibrium of a Majority-Rule Division Game." Journal of Economic Theory 61: 290-301.

Bennett, Elaine. 1983a. "The Aspiration Approach to Predicting Coalition Formation and Payoff Distributions in Sidepayment Games." International Journal of Game Theory 12: $1-28$.

Bennett, Elaine. 1983b. "Characterization Results for Aspirations in Games with Sidepayments." Journal of Mathematical Social Science 4: 229-241.

Bennett, Elaine, and Eric Van Damme. 1991. "Demand Commitment Bargaining: The Case of Apex Games." In Game Equilibrium Models III: Strategic Bargaining, edited by R. Selten. Berlin: Springer Verlag.

Browne, Eric C. and John Dreijmanis. 1982. Government Coalitions in Western Democracies. New York: Longman, Inc.

Browne, Eric C., and Mark N. Franklin. 1973. "Aspects of Coalition Payoffs in European Parliamentary Democracies." American Political Science Review 453-469.

Browne, Eric C., and John P. Frendreis. 1980. "Allocating Coalition Payoffs by Conventional Norm: An Assessment of the Evidence from Cabinet Coalition Situations." American Journal of Political Science 24: 753-768.

Browning, Clyde E. 1973. "The Geography of Federal Outlays." Studies in Geography No. 4. Chapel Hill: University of North Carolina Department of Geography.

Calvert, Randall, and Nathan Dietz. 1996. "Legislative Coalitions in a Bargaining Model with Externalities." Unpublished manuscript, University of Rochester.

Carmignani, Fabrizio. 2001. "Cabinet Formation in Coalition Systems." Scottish Journal of Political Economy 48: 313-329.

Dahl, Robert A. 1956. A Preface to Democratic Theory. Chicago: University of Chicago Press. 
Diermeier, Daniel, and Timothy J. Feddersen. 1998. "Cohesion in Legislatures and the Vote of Confidence Procedure." American Political Science Review 92: 611-622.

Diermeier, Daniel, and Antonio Merlo 1999. "An Empirical Investigation of Coalitional Bargaining Procedures." Northwestern University, Center for Mathematical Studies in Economics and Management Science, Discussion Paper No. 1267.

Diermeier, Daniel, Hulya Eraslan, and Antonio Merlo. 2002. "Bicameralism and Government Formation." Unpublished manuscript.

Erie, Stephen P. 1978. "Politics, the Public Sector, and Irish Social Mobility: San Francisco, 1870-1900." Western Political Quarterly 31: 274-289.

Eraslan, Hulya. 2002. "Uniqueness of Stationary Equilibria Payoffs in the Baron-Ferejohn Model." Journal of Economic Theory 103: 11-30.

Gamson, William A. 1961. "A Theory of Coalition Formation." American Sociological Review 26: 373-382.

Gibson, Edward L., Calvo, Ernesto F., and Tulia G. Falleti. 1999. "Reallocative Federalism: Overrepresentation and Public Spending in the Western Hemisphere." Unpublished Manuscript.

Harrington, Joseph. 1989. "The Advantageous Nature of Risk Aversion in a Three-Player Bargaining Game Where Acceptance of a Proposal Requires a Simple Majority." Economics Letters 30: 195-200.

Harrington, Joseph. 1990a. "The Power of the Proposal Maker in a Model of Endogenous Agenda Formation." Public Choice 64: 1-20.

Harrington, Joseph. 1990b. "The Role of Risk Preferences in Bargaining When Acceptance of a Proposal Requires Less than Unanimous Approval." Journal of Risk and Uncertainty 3: 135-154.

Holden, Matthew. 1973. White Man's Burden. New York: Chandler. 
Horiuchi, Yusaku, and Jun Saito. 2001. "Reapportionment and Redistribution: A Consequence of the Electoral Reform in Japan." Unpublished manuscript, National University of Singapore.

Isbell, J.R. 1956. "A Class of Majority Games." Quarterly Journal of Math. Oxford 7: $183-187$.

Jackson, Matthew, and Boaz Moselle. 2002. "Coalition and Party Formation in a Legislative Voting Game." Journal of Economic Theory 103: 49-87.

Johnston, Michael. 1979. "Patrons and Clients, Jobs and Machines: A Case Study of the Uses of Patronage." American Political Science Review 73: 385-398.

Laver, Michael, and W. Ben Hunt. 1992. Policy and Party Competition. New York: Routledge.

LeBlanc, William, James M. Snyder, Jr., and Micky Tripathi. 2000. "Majority-Rule Bargaining and the Under Provision of Public Investment Goods." Journal of Public Economics 75: 21-47.

Lee, Frances, and Bruce L. Oppenheimer. 1999. Sizing Up the Senate: The Unequal Consequences of Equal Representation. Chicago: University of Chicago Press.

Levitt, Steven D. and James Snyder. 1995. "Political Parties and Federal Outlays." American Journal of Political Science 39:958-980.

McCarty, Nolan M. 2000a. "Proposal Rights, Veto Rights, and Political Bargaining." American Journal of Political Science 44: 506-522.

McCarty, Nolan M. 2000b. "Presidential Pork: Executive Veto Power and Distributive Politics." American Political Science Review 94: 117-129.

McKelvey, Richard D., and Raymond Riezman. 1992. "Seniority in Legislatures." American Political Science Review 86: 951-965. 
Morelli, Massimo. 1999. "Demand Competition and Policy Compromise in Legislative Bargaining." American Political Science Review 93: 809-820.

Mueller, Wolfgang C., and Kaare Strom. 2000. Coalition Governments in Western Europe. Oxford: Oxford University Press.

Norman, Peter. 2002. "Legislative Bargaining and Coalition Formation." Journal of Economic Theory 102: 322-353.

Owens, John R., and Larry L. Wade. 1984. "Federal Spending in Congressional Districts." Western Political Quarterly 37:404-23.

Penrose, L.S. 1946. "The Elementary Statistics of Majority Voting." Journal of the Royal Statistical Society 109: 53-57.

Rakove, Milton. 1975. Don't Make No Waves, Don't Back No Losers. Bloomington, IN: Indiana University Press.

Ritt, Leonard G. 1976. "Committee Position, Seniority, and the Distribution of Government Expenditures." Public Policy 24: 469-497.

Rodden, Jonathan. 2002. "Strength in Numbers? Representation and Redistribution in the European Union." European Union Politics 3: 151-175.

Rubinstein, Ariel. 1982. "Perfect Equilibrium in a Bargaining Model." Econometrica 50: 97-109.

Schofield, Norman. 1976. "The Kernel and Payoffs in European Government Coalitions." Public Choice 26: 29-49.

Schofield, Norman, and Michael Laver. 1985. "Bargaining Theory and Portfolio Payoffs in European Coalition Governments 1945-1983." British Journal of Political Science 15: 143-164.

Selten, Reinhardt. 1981. "A Noncooperative Model of Characteristic Function Bargaining." In Essays in Game Theory and Mathematical Economics in Honor of Oskar 
Morgenstern, edited by Robert Aumann, John Harsanyi, Werner Hildebrand, Michael Muschler, M.A. Perls, Joachim Rosenmuller, Reinhardt Selten, Martin Shubik, and G.L. Thompson. Mannheim: Bibliographisches Institut.

Selten, Reinhardt. 1992. "A Demand Commitment Model of Coalitional Bargaining." In Rational Interaction, edited by Reinhardt Selten. New York: Springer-Verlag.

Shapley, Lloyd S., and Martin Shubik. 1954. "A Method for Evaluating the Distribution of Power in a Committee System." American Political Science Review 48: 787-792.

Shepsle, Kenneth A. 1978. The Giant Jigsaw Puzzle. Chicago: University of Chicago Press.

Snyder, Ting and Ansolabehere. 2002. "Legislative Bargaining Under Weighted Voting." Unpublished manuscript, MIT.

Strauss, Aaron B. 2003. "An Algorithm to Calculate Minimum Integer Weights for Arbitrary Voting Games." Masters of Science Thesis. Department of Computer Science, Massachusetts Institute of Technology.

Strom, Kaare, Ian Budge, and Michael J. Laver. 1994. "Constraints on Cabinet Formation in Parliamentary Democracies." American Journal of Political Science 38: 303-335.

Stromberg, David. 2001. "Radio's Impact on Public Spending." Unpublished manuscript, Institute for International Economic Studies, Stockholm University.

Wallis, John J. 1987. "Employment, Politics and Economic Recovery during the Great Depression." Review of Economics and Statistics 69: 516-20.

Wallis, John J. 1996. "What Determines the Allocation of National Government Grants to the States?" NBER Historical Paper No. 90.

Warwick, Paul V. 1994. Government Survival in Parliamentary Democracies. Cambridge: Cambridge University Press. 
Warwick, Paul V., and James N. Druckman. 2001. "Portfolio Salience and the Proportionality of Payoffs in Coalition Governments." British Journal of Political Science 31: 627-649.

Winter, Eyal. 1996. "Voting and Vetoing." American Political Science Review 90: 813-823.

Wright, Gavin. 1974. "The Political Economy of New Deal Spending: An Econometric Analysis." Review of Economics and Statistics." 56: 30-38. 


\begin{tabular}{|l|c|c|}
\hline \multicolumn{3}{|c|}{ Table 1 } \\
Voting Weight and Formateur Effects \\
in the Allocation of Cabinet Posts \\
in Parliamentary Governments, 1946-2001 \\
Dep. Var. = Share of Cabinet Posts \\
\hline & Unweighted & PM Weighted \\
\hline Share of Voting Weight & $1.12^{*}$ & $.98^{*}$ \\
& $(.05)$ & $(.05)$ \\
Formateur & $.15^{*}$ & $.25^{*}$ \\
& $(.015)$ & $(.01)$ \\
Constant & $.07^{*}$ & $.06^{*}$ \\
& $(.01)$ & $(.01)$ \\
\hline R-squared & .72 & .82 \\
\# Observations & 682 & 682 \\
\hline
\end{tabular}

Clustered standard errors in parentheses, where each cluster is a government.

${ }^{*}$ statistically significant at the .01 level 


\begin{tabular}{|c|c|c|c|c|}
\hline \multicolumn{5}{|c|}{$\begin{array}{c}\text { Table } 2 \\
\text { Seat Shares, Formateur Effects } \\
\text { and the Allocation of Cabinet Posts } \\
\text { in Parliamentary Governments, 1946-2001 } \\
\text { Dep. Var. = Share of Cabinet Posts }\end{array}$} \\
\hline & \multicolumn{2}{|c|}{ Share of Seats In Gov't } & \multicolumn{2}{|c|}{ Share of All Seats } \\
\hline & $\begin{array}{c}\text { Unweighted } \\
\text { (1) }\end{array}$ & $\begin{array}{c}\text { PM Weighted } \\
(2)\end{array}$ & $\begin{array}{c}\text { Unweighted } \\
(3)\end{array}$ & $\begin{array}{c}\text { PM Weighted } \\
(4)\end{array}$ \\
\hline Share of Seats & $\begin{array}{l}.79^{*} \\
(.02)\end{array}$ & $\begin{array}{l}.69^{*} \\
(.02)\end{array}$ & $\begin{array}{l}1.09^{*} \\
(.04)\end{array}$ & $\begin{array}{l}.96^{*} \\
(.04)\end{array}$ \\
\hline Formateur & $\begin{array}{c}.01 \\
(.01)\end{array}$ & $\begin{array}{l}.13^{*} \\
(.01)\end{array}$ & $\begin{array}{l}.07^{*} \\
(.01)\end{array}$ & $\begin{array}{l}.19^{*} \\
(.01)\end{array}$ \\
\hline Constant & $\begin{array}{l}.08^{*} \\
(.01)\end{array}$ & $\begin{array}{l}.07^{*} \\
(.01)\end{array}$ & $\begin{array}{l}.11^{*} \\
(.01)\end{array}$ & $\begin{array}{l}.09^{*} \\
(.01)\end{array}$ \\
\hline $\begin{array}{l}\text { R-squared } \\
\# \text { Observations }\end{array}$ & $\begin{array}{l}.87 \\
682\end{array}$ & $\begin{array}{l}.91 \\
682\end{array}$ & $\begin{array}{l}.78 \\
682\end{array}$ & $\begin{array}{l}.86 \\
682\end{array}$ \\
\hline
\end{tabular}

Clustered standard errors in parentheses, where each cluster is a government.

* statistically significant at the .01 level 


\begin{tabular}{|l|c|c|c|c|}
\hline \multicolumn{5}{|c|}{ Table 3 } \\
Probit Estimates of the Likelihood \\
that a Party is Formateur \\
in Parliamentary Governments, 1946-2001 \\
Dep. Var. = 1 if party is formateur \\
\hline Share of Voting Weight & $(1)$ & $(2)$ & $(3)$ & $(4)$ \\
& $7.77^{*}$ & - & $1.58^{*}$ & 1.58 \\
Share of Seats & $(.43)$ & & $(.69)$ & $(.70)$ \\
& - & $6.64^{*}$ & $1.63^{*}$ & .86 \\
Largest Party & - & $(.28)$ & $(.59)$ & $(.63)$ \\
& & - & $1.64^{*}$ & $1.46^{*}$ \\
Second Largest Party & - & - & $(.25)$ & $(.26)$ \\
& & & $0.85^{*}$ & $0.87^{*}$ \\
Incumbent Formateur & - & - & - & $.20)$ \\
& & & & $\left(.14^{*}\right.$ \\
Constant & $-2.65^{*}$ & $-2.45^{*}$ & $-2.39^{*}$ & $-2.38^{*}$ \\
& $(.11)$ & $(.07)$ & $(.10)$ & $(.11)$ \\
\hline log-likelihood & -480.6 & -449.3 & -410.6 & -367.8 \\
pseudo-R-squared & .33 & .37 & .43 & .45 \\
\# Observations & 1744 & 1744 & 1744 & 1591 \\
\hline
\end{tabular}

Clustered standard errors in parentheses, where each cluster is a government.

* statistically significant at the .01 level 
Figure 1

Relationship Between Seats and Weights in Coalition Governments, 1946-2001

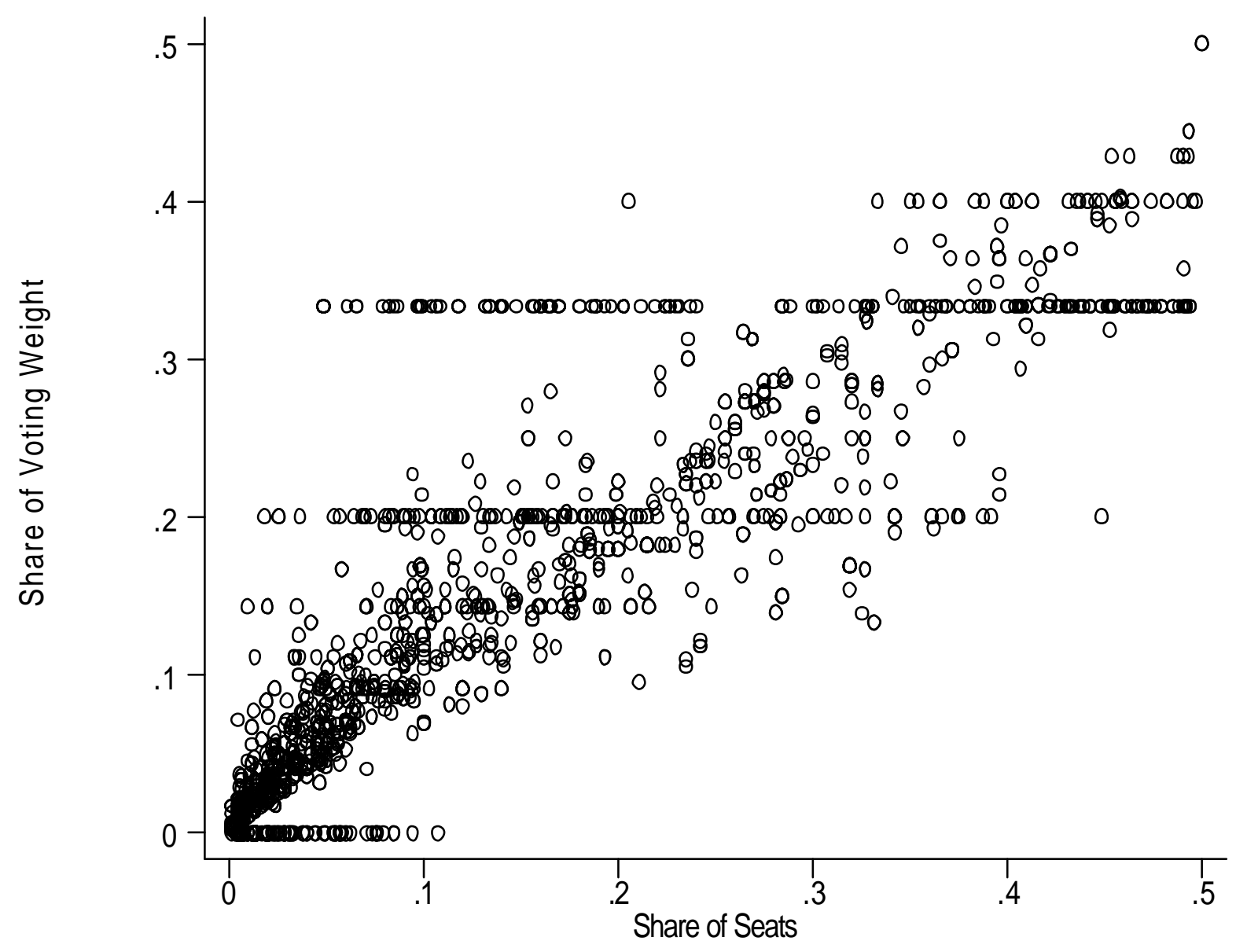

